PERM JOURNAL OF PETROLEUM AND MINING ENGINEERING

ВЕСТНИК ПНИПУ. ГЕОЛОГИЯ. НЕФТЕГАЗОВОЕ И ГОРНОЕ ДЕЛО

ISSN 2224-9923

Volume/Tom 19 №1 2019

http://vestnik.pstu.ru/geo/

UDC 622.276.72(470.53)

Article / Статья

(C) PNRPU / ПНИПУ, 2019

\title{
THE STUDY OF LUMINESCENT-BITUMEN CHARACTERISTICS OF ORGANIC SUBSTANCES OF DOMANIK TYPE DEPOSITS IN THE PERM REGION
}

\section{Aleksandr V. Raznicyn, Oleg A. Melkishev \\ Perm National Research Polytechnic University (29, Komsomolskiy ave., Perm, 614000, Russian Federation) \\ ИЗУЧЕНИЕ ЛЮМИНЕСЦЕНТНО-БИТУМИНОЛОГИЧЕСКИХ ХАРАКТЕРИСТИК ОРГАНИЧЕСКОГО ВЕЩЕСТВА ОТЛОЖЕНИЙ ДОМАНИКОВОГО ТИПА НА ТЕРРИТОРИИ ПЕРМСКОГО КРАЯ}

\section{А.В. Разницын, О.А. Мелкишев}

Пермский национальный исследовательский политехнический университет (614000, Россия, г. Пермь, Комсомольский пр., 29)

Received / Получена: 11.07.2018. Accepted / Принята: 14.01.2019. Published / Опубликована: 29.03.2019

\section{Key words:}

luminescent-bitumen analysis, domanik type deposits, organic matter, bitumoid ratio, organic carbon content, domanian horizon, statistical characteristics, source deposits, generation potential, Uspensky-Vassoevich graph, allochtonic bitumen, GIS, autochthonous bitumens, correlation coefficient multivariate statistical models.

\begin{abstract}
The reduction of the resource base of oil and gas in the old oil and gas producing areas, including the Perm region, leads to the need for a detailed study of the processes of generation, migration and accumulation of hydrocarbons. Successful prediction of petroleum potential is impossible without studying the geochemical properties of oil and gas source deposits. Determination of the content of dispersed organic matter in the rock, the degree of bituminousness of the rocks, the composition of the organic matter allow us to estimate the generation potential of the sediments and use it to assess the oil and gas content of the territory.

On the territory of the Perm region the Domanik type deposits are the main source of hydrocarbons for the oil and gas fields.

The deposits of the Domanik type include the Sargayevsky and Domanik horizons of the Middle Frasnian substage, the Mendym horizon and the upper undifferentiated stratum of the Upper Frasnian substage, also the Famennian and Tournaisian layers. These deposits are associated with the development of the Kama-Kinel system of deflections (KKSD). The article contains a statistical analysis of the chemical and bitumen characteristics of the Domanik type sediments, the relationships between well log data and the results of luminescent bitumen research are considered, multidimensional statistical models for predicting organic carbon content based on GIS data are built, organic carbon content maps for received models are created.

It was found that, within the entire strata, Domanic sediments have very good oil source properties. By the multidimensional statistical modelling and the construction of maps of organic carbon, it was revealed that the highest concentrations of organic matter in the Domanik horizon are observed in the north-east, central and southern parts of the Perm Region.
\end{abstract} Пермский край, приводит к необходимости детального изучения процессов генерации, миграции и аккумуляции углеводородов. Успешное прогнозирование нефтегазоносности невозможно без изучения геохимических свойств нефтегазоматеринских отложений. Определение содержания рассеянного органического вещества в породе степени битуминозности пород, компонентного состава органического вещества позволяет оценивать генерационный потенциал отложений и использовать его для прогноза нефтегазоносности территории.

На территории Пермского края к нефтегазоматеринским относятся отложения доманикового типа, которые считаются основным источником углеводородов для нефтегазоносных комплексов Пермского края.

К отложениям доманикового типа (формации) относятся саргаевский и доманиковый горизонты среднефранского подъяруса, мендымский горизонт и верхняя нерасчлененная толща верхнефранского подъяруса, а также фаменский и турнейский ярусы. Данные отложения связаны с развитием Камско-Кинельской системы прогибов.

В статье выполнены статистический анализ химико-битуминологических характеристик отложений доманикового типа, рассмотрены зависимости между данными геофизических исследований скважин (ГИС) и результатами люминесцентнобитуминологических исследований, построены многомерные статистические модели прогноза содержания органического углерода по данным ГИС, построены карты содержания органического углерода по полученным моделям.

В результате проведенных исследований было установлено, что в пределах всей толщи очень хорошими нефтематеринскими свойствами обладают отложения доманикового времени. Благодаря применению многомерных статистических моделей и построению карт содержания органического углерода было выявлено, что повышенные концентрации органического вещества в доманиковом горизонте наблюдаются в северо-восточной, центральной и южной частях Пермского края.

\footnotetext{
Aleksandr V. Raznicyn - PhD student at the Department of Oil and Gas Technologies (tel.: +007 34221984 11, e-mail: alexandrraznitsyn@gmail.com).

Oleg A. Melkishev (Author ID in Scopus: 55531674700) - PhD, Associate Professor at the Department of Geology of Oil and Gas (tel.: +007342 21984 11, e-mail: melkishev@pstu.ru). The contact person for correspondence.
}

Разницын Александр Вячеславович - аспирант кафедры нефтегазовых технологий (тел.: +007 342219 84 11, e-mail: alexandrraznitsyn@gmail.com) Мелкишев Олег Александрович - кандидат технических наук, доцент кафедры геологии нефти и газа (тел.: +007342 219 84 11, e-mail: melkishev@pstu.ru). Контактное лицо для переписки. 


\section{Introduction}

The geochemical characteristics of organic matter are the basis of the sedimentary migration theory of oil formation. A detailed study of the luminescent-bitumen characteristics of organic matter (OM) has made it possible in many petroleum regions, provinces, and provinces to clarify the generation potential of oil source rocks, the features of organic matter migration in petroleum complexes and predict hydrocarbon deposits [1-9]. Therefore, the study of these characteristics for deposits of the Domanik type of the Perm Territory plays an important role.

Domanic type deposits are associated with the development of the Kama-Kinel deflection system (KKSD). Sedimentation occurred from the Sargayevsky to the Early Tournasian time inclusive. The deposits of the Domanik type (formation) include the Sargayevsky and Domanik horizons of the Middle Frasnian substage, the Mendym horizon and the upper undifferentiated stratum of the Upper Frasnian substage, as well as the Famennian and Tournaisian layers.

In general, Domanic deposits are represented by bituminous clayey dark gray, almost black limestone interbedded with marls of the same color, lime - clay - siliceous shales and flints [6-13].

In order to study the geochemical features of the Domanic deposits, the results of luminescent-bitumen analysis of 313 core samples of domanicoid rock formations taken from 88 wells of 75 exploration areas were analyzed.

The main geochemical indicators determined during chemical and bitumen studies are the content in the rock of dispersed organic matter (DOM, \%), organic carbon $\left(\mathrm{C}_{\mathrm{org}}, \%\right)$, insoluble residue of the rock (IR, \%), petroleum ether bitumoide $\left(\mathrm{B}_{\mathrm{pe}}, \%\right)$, chloroform bitumoide $\left(\mathrm{B}_{\mathrm{hb}}, \%\right)$, alcohol benzol bitumoide $\left(\mathrm{B}_{\mathrm{ab}}, \%\right)$, humic acids $\left(\mathrm{G}_{\mathrm{a}}, \%\right)$, as well as the bitumoide coefficient $(\beta, \%)$ [14-20].

\section{Statistical analysis of chemical and bitumen indicators of the Domanic type deposits}

Table 1 presents the main statistical characteristics [21-26] of geochemical indicators of the Domanik type deposits for some regions. The table shows that the highest content of organic carbon $\left(\mathrm{C}_{\mathrm{org}}=5.59 \%\right)$ and, therefore, dispersed organic matter $(\mathrm{DOM}=$ $=7.08 \%$ ) is observed on the territory of the Solikamsk depression. The explanation of this fact is that this territory during the development of the KKSD was mostly located in the area of uncompensated depressions and deflections which are favorable for the accumulation of organic matter. The value of the bitumoid coefficient $(\beta=15.68 \%)$ with a high content of organic matter $\left(\mathrm{C}_{\text {org }}=5.59 \%\right)$ indicates the presence of migrated bitumoids $[17,27]$. The high concentration of chloroform bitumoide $\left(\mathrm{B}_{\mathrm{hb}}=1.06 \%\right)$, as well as the large value of the neutrality coefficient $\left(\mathrm{K}_{\mathrm{n}}=3.44\right)$ indicate a significant restoration of bitumoids and their oil character. It is also worth noting the high percentage of the insoluble residue of the rock (IR $=52.44 \%)$, which is the largest among the considered tectonic elements. If accept the fact that the sediments mostly accumulated in the depressive zones of the KKSD, then it can be assumed that the insoluble residue of the rock contains a significant proportion of the pelitic fraction (clay particles). The presence of this fraction favors the adsorption and preservation of organic matter on the surface of the particles.

The lowest content of organic carbon $\left(\mathrm{C}_{\text {org }}=3.30 \%\right)$ and, therefore, dispersed organic matter $(\mathrm{DOM}=4.15 \%)$ is observed for the territory of the Bashkir arch. From the Sargayevsky to the Tournaisian age, facial conditions of the shallow shelf and platform lagoons prevailed in this area. The high value of the bitumoide coefficient $(\beta=39.46 \%)$ confirms the high proportion of epigenetic bitumoide $[17,18]$. The high concentration of 
chloroformbitumoide $\left(\mathrm{B}_{\mathrm{hb}}=1.42 \%\right)$, as well as the large value of the neutrality coefficient $(\mathrm{Kn}=3.23)$ indicate a significant restoration of bitumoids and their oil character. It is also worth noting the low percentage of the insoluble residue of the rock ( $\mathrm{IR}=19.98 \%$ ), which is the smallest among the considered tectonic elements.

Table 1

The main statistical characteristics of the Domanik type depositsgeochemical indicators

\begin{tabular}{|c|c|c|c|c|c|c|c|c|c|}
\hline Area & $\mathrm{C}_{\text {org }}, \%$ & I & $\mathrm{B}_{\mathrm{pe}}, 10^{-2} \%$ & $\mathrm{~B}_{\mathrm{hb}}, 10^{-2} \%$ & $\mathrm{~B}_{\mathrm{ab}}, 10^{-2} \%$ & $\mathrm{Ga}, 10^{-2} \%$ & & & $\begin{array}{c}\mathrm{K}_{\mathrm{n}} \\
\left(\mathrm{B}_{\mathrm{hb}} / \mathrm{B}_{\mathrm{ab}}\right) \\
\end{array}$ \\
\hline \multirow{2}{*}{ Bashkir arch } & 02 & 84 & .26 & 05.43 & 41.7 & .28 & 17.59 & 39.4 & $3.23 \pm 5.24$ \\
\hline & 0.06 & 0.06 & 60 & & 1.00 & & $0.53-57.60$ & 0.3 & $0.10-24.04$ \\
\hline \multirow{2}{*}{$\begin{array}{l}\text { Bym-Kungur } \\
\text { monocline }\end{array}$} & 2.82 & $5.60 \pm 3.33$ & $.16 \pm 3.83$ & $140.50 \pm 146.04$ & $100.99 \pm 95.73$ & $0.10 \pm 0.28$ & 37.57 & 26.63 & $3.15 \pm 5.61$ \\
\hline & 7.24 & 2.28 & 0.12 & .00 & 8.0 & 0.0 & 4.8 & 0.8 & $0.25-32.05$ \\
\hline \multirow{2}{*}{$\begin{array}{l}\text { Upper Kama } \\
\text { depression }\end{array}$} & 3.23 & 5.92 & 4.34 & $94.32 \pm 140.70$ & 72.54 & $\underline{0.82 \pm 2.15}$ & $48.25 \pm 33.01$ & 19.84 & $1.44 \pm 2.27$ \\
\hline & & 0.05 & & & & & & 0.3 & $0.19-8.00$ \\
\hline \multirow{2}{*}{ Visim monocline } & $5.26=$ & 6.95 & 1.64 & $\underline{49.32 \pm 75.75}$ & 8.34 & \pm 2.34 & \pm 35.00 & $11.81 \pm 14.00$ & $2.32 \pm 2.97$ \\
\hline & $0.05-24.33$ & & & & & & 0.51 & 0.48 & $0.17-10.64$ \\
\hline \multirow{2}{*}{$\begin{array}{l}\text { Advanced folds } \\
\text { of Urals }\end{array}$} & $4.07=$ & 5.27 & .22 & 15. & 11.3 & $0.2^{7}$ & 50.34 & 5.23 & $1.41 \pm 1.06$ \\
\hline & & & & & & & & & $0.48-3.99$ \\
\hline \multirow{2}{*}{$\begin{array}{l}\text { Solikamsk } \\
\text { depression }\end{array}$} & $5.59 \pm 6.38$ & $7.08 \pm 7.98$ & $2.20 \pm 3.87$ & $105.64 \pm 171.22$ & $41.61 \pm 47.96$ & $2.52 \pm 6.13$ & $52.44 \pm 32.51$ & $15.68 \pm 24.78$ & $3.44 \pm 6.20$ \\
\hline & $1.08-46.14$ & $1.17-57.68$ & $0.00-20.00$ & $1.00-500.00$ & $2.00-214.00$ & $0.00-3.13$ & $3.46-99.62$ & $0.26-94.58$ & $0.19-32.05$ \\
\hline
\end{tabular}

Note : here and in Table 2 in the numerator - the arithmetic mean \pm standard deviation; denominator - scale values $(\min -\max )$.

To determine the autochthonousness and allochthonousness of bitumoids, the UspenskyVassoevich law (schedule) is applied. Figure 1 shows the correlation field between $\beta$ and $\mathrm{C}_{\text {org }}$. Most of the studied rocks samples of the Domanik deposits in the Perm region is characterized by the content of allochthonous bitumoids.

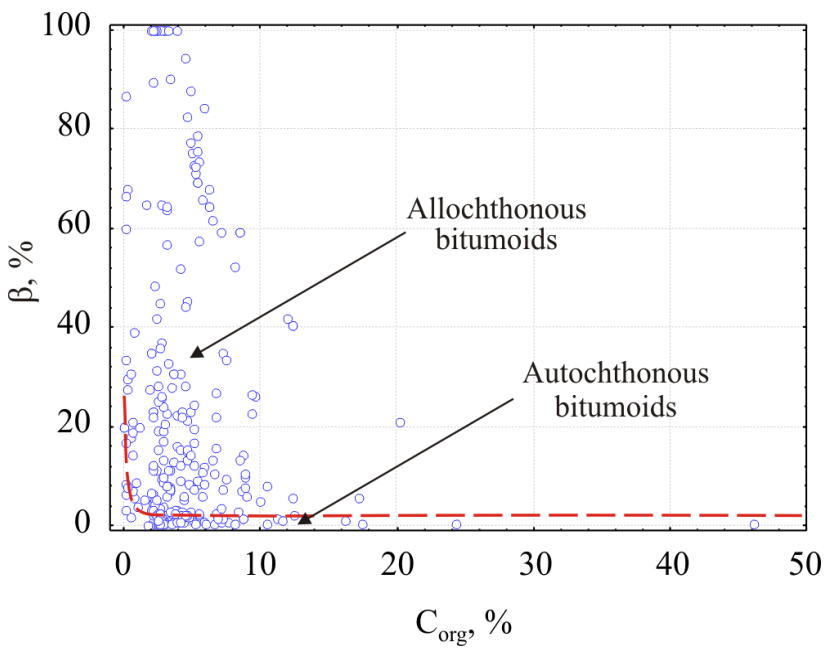

Figure 1.Correlation field between $\beta$ and $\mathrm{C}_{\mathrm{org}}$ (for the Domanik type deposits). Dotted line separates allochthonous and autochthonous bitumoids [12]

Table 2 shows the main statistical characteristics of the studied sediments geochemical parameters.
The analysis shows that among all of the studied Domanik type deposits, the Domanik horizon is characterized by maximum average values in almost all geochemical parameters: $\mathrm{C}_{\text {org }}=5.66 \%, \mathrm{~B}_{\mathrm{pe}}=0.06 \%, \mathrm{~B}_{\mathrm{hb}}=2.11 \%$ $\mathrm{B}_{\mathrm{ab}}=1.13 \%, \beta=33.68 \%, \mathrm{DOM}=7.11 \%$. According to the classification of K.F. Rodionova the Domanik horizon belongs to the category of very good source rocks [28].

\section{Determination of statistical relationships between GIS data and the results of bituminous studies of domanic deposits}

In this paper, the results of luminescentbitumen analysis of the domanic sediments were compared with the well logging data of the following methods:

- gamma ray logging (GR);

- neutron gamma logging (NGR);

- gamma-gamma density logging (GGD);

- thermal neutron neutron-neutron logging (TNN), 1-big probe, 2 - small probe;

- acoustic logging (A).

The possibility of well log methods using for estimating the content of organic carbon is given in [29-38]. 
The main statistical characteristics of the geochemical indicators of Sargayevsky,

Domanik and Mendym horizons, the undifferentiated stratum

of the Upper Frasnian substage, the Famennian and Tournaisian tiers

\begin{tabular}{|c|c|c|c|c|c|c|c|c|c|}
\hline Stratigraphic unit & $\mathrm{C}_{\text {org }}, \%$ & IR, \% & $\mathrm{B}_{\mathrm{pe}}, 10^{-2} \%$ & $\mathrm{~B}_{\mathrm{hb}}, 10^{-2} \%$ & $\mathrm{~B}_{\mathrm{ab}}, 10^{-2} \%$ & $\mathrm{Ga}, 10^{-2} \%$ & $\beta, \%$ & $\mathrm{~K}_{\mathrm{n}}\left(\mathrm{B}_{\mathrm{hb}} / \mathrm{B}_{\mathrm{ab}}\right)$ & DOM, \% \\
\hline \multirow{2}{*}{$\mathrm{C}_{1} \mathrm{t}$} & $3.38 \pm 3.05$ & $\underline{48.64 \pm 35.38}$ & $0.02 \pm 0.04$ & $\underline{0.24 \pm 0.65}$ & $0.25 \pm 0.38$ & $0.95 \pm 2.36$ & $\underline{11.84 \pm 19.92}$ & $\underline{1.30 \pm 3.66}$ & $4.52 \pm 4.06$ \\
\hline & $0.05-17.50$ & $0.53-99.50$ & $0.00-0.24$ & $0.00-5.00$ & $0.00-2.14$ & $0.00-15.60$ & $0.26-86.87$ & $0.17-30.83$ & $0.05-23.28$ \\
\hline \multirow{2}{*}{$\mathrm{D}_{3} \mathrm{fm}$} & $4.68 \pm 7.24$ & $46.76 \pm 33.39$ & $0.02 \pm 0.03$ & $\underline{0.58 \pm 1.22}$ & $0.20 \pm 0.25$ & $1.52 \pm 5.42$ & $17.57 \pm 24.72$ & $2.65 \pm 5.41$ & $6.03 \pm 9.29$ \\
\hline & $0.05-46.14$ & $0.51-99.62$ & $0.00-0.16$ & $0.01-5.00$ & $0.02-1.48$ & $0.00-31.30$ & $0.41-100.00$ & $0.13-32.05$ & $0.05-57.68$ \\
\hline \multirow{2}{*}{$\mathrm{D}_{3} \mathrm{f}_{3}$} & $3.29 \pm 2.50$ & $32.41 \pm 20.34$ & $0.01 \pm 0.01$ & $0.35 \pm 1.03$ & $0.25 \pm 0.28$ & $\underline{0.51 \pm 1.69}$ & $10.06 \pm 18.27$ & $1.56 \pm 4.42$ & $4.49 \pm 3.40$ \\
\hline & $0.29-12.48$ & $3.02-84.39$ & $0.00-0.05$ & $0.00-5.00$ & $0.00-0.83$ & $0.00-8.00$ & $0.00-78.76$ & $0.00-21.28$ & $0.29-16.60$ \\
\hline \multirow{2}{*}{$\mathrm{D}_{3} \mathrm{mn}$} & $3.63 \pm 2.15$ & $29.68 \pm 20.40$ & $0.03 \pm 0.08$ & $1.19 \pm 1.77$ & $0.54 \pm 0.42$ & $0.59 \pm 0.13$ & $28.38 \pm 34.20$ & $\underline{3.39 \pm 6.60}$ & $4.63 \pm 2.68$ \\
\hline & $0.57-9.92$ & $5.35-97.3$ & $\overline{0.00-0.31}$ & $0.00-5.00$ & $\overline{0.00-1.48}$ & $\overline{0.00-11.80}$ & $0.00-100.00$ & $0.25-32.05$ & $\overline{0.57-12.40}$ \\
\hline \multirow{2}{*}{$\mathrm{D}_{3} \mathrm{dm}$} & $5.66 \pm 3.22$ & $38.21 \pm 20.52$ & $0.06 \pm 0.10$ & $2.11 \pm 1.88$ & $1.13 \pm 1.03$ & $0.20 \pm 0.51$ & $33.68 \pm 28.44$ & $3.93 \pm 5.38$ & $7.11 \pm 3.78$ \\
\hline & $0.51-20.25$ & $4.41-95.68$ & $\overline{0.00-0.80}$ & $\overline{0.00-5.00}$ & $\overline{0.04-5.00}$ & $0.00-4.00$ & $0.33-100.00$ & $0.25-24.04$ & $0.51-23.90$ \\
\hline \multirow{2}{*}{$\mathrm{D}_{3} \mathrm{sr}$} & $4.90 \pm 3.61$ & $43.07 \pm 29.05$ & $\underline{0.06 \pm 0.06}$ & $2.08 \pm 2.19$ & $\underline{0.70 \pm 1.12}$ & $0.72 \pm 2.55$ & $\underline{31.79 \pm 36.10}$ & $\underline{4.71 \pm 5.53}$ & $6.50 \pm 4.79$ \\
\hline & $\overline{0.44-16.19}$ & $7.71-98.95$ & $\overline{0.00-0.16}$ & $\overline{0.01-5.00}$ & $\overline{0.06-5.00}$ & $\overline{0.00-11.80}$ & $0.55-100.00$ & $\overline{0.13-15.97}$ & $\overline{0.44-20.24}$ \\
\hline
\end{tabular}

To bring the log curves to a general form and eliminate the influence of units of measurement, different dates of research and different downhole tools, the log data were standardized using the following formula:

$$
x_{\mathrm{st}}=\left(x_{i}-x_{\mathrm{av}}\right) / x_{\mathrm{std}},
$$

where $x_{\mathrm{st}}$ - standardized value of the log data; $x_{i}-i$-th indication of the log data; $x_{\mathrm{av}}-$ average value of the $\log$ data throughout the domanicoid formation; $x_{\text {std }}-$ standard deviation of the $\log$ data for the whole domanicoid formation.

Use of this formula allows reducing the units for each type of logging, since the same logging methods may have different units.

The missing well logs in some wells were calculated using regression analysis [21, 25-26, 39].

In order to determine the links between geochemical indices and $\log$ data, a correlation matrix was constructed for the Domanic sediments of the Perm region (Table 3 ).

According to the Table 3, 23 paired correlation coefficients out of 54 are statistically significant. The highest correlation coefficients are established between the following pairs of indicators: $\mathrm{B}_{\mathrm{hb}}$ и $\mathrm{G}_{\mathrm{a}}$

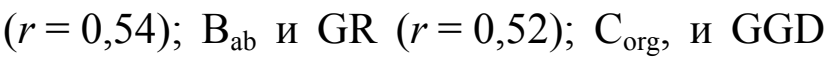
$(r=-0,50)$.
Table 3

Correlation matrix between well log data and geochemical indicators of the Domanik type deposits in the Perm Region

\begin{tabular}{|l|c|c|c|c|c|c|c|c|c|}
\hline $\begin{array}{c}\text { Indica- } \\
\text { tors }\end{array}$ & $\begin{array}{c}\mathrm{C}_{\mathrm{org}}, \\
\%\end{array}$ & $\begin{array}{c}\mathrm{IR}, \\
\%\end{array}$ & $\begin{array}{c}\mathrm{B}_{\mathrm{pe}}, \\
10^{-2} \%\end{array}$ & $\begin{array}{c}\mathrm{B}_{\mathrm{hb}}, \\
10^{-2} \%\end{array}$ & $\begin{array}{c}\mathrm{B}_{\mathrm{ab}}, \\
10^{-2} \%\end{array}$ & $\begin{array}{c}\mathrm{G}_{\mathrm{a}}, \\
10^{-2} \%\end{array}$ & $\beta, \%$ & $\begin{array}{c}\mathrm{K}_{\mathrm{n}} \\
\left(\mathrm{B}_{\mathrm{hb}} \mathrm{B}_{\mathrm{ab}}\right)\end{array}$ & $\begin{array}{c}\mathrm{DOM}, \\
\%\end{array}$ \\
\hline GR & $0.31^{*}$ & $0.37^{*}$ & $0.47^{*}$ & $0.54^{*}$ & $0.52^{*}$ & -0.13 & $0.29^{*}$ & $0.32^{*}$ & $0.42^{*}$ \\
\hline NGR & $-0.25^{*}$ & -0.23 & $-0.38^{*}$ & $-0.46^{*}$ & $-0.40^{*}$ & 0.06 & $-0.35^{*}$ & $-0.28^{*}$ & $-0.32^{*}$ \\
\hline TNN1 & $-0.45^{*}$ & 0.09 & 0.21 & -0.23 & 0.10 & -0.06 & -0.32 & -0.35 & 0.09 \\
\hline TNN2 & $-0.30^{*}$ & 0.07 & 0.33 & -0.08 & 0.30 & -0.08 & -0.21 & -0.31 & 0.08 \\
\hline GGD & $-0.50^{*}$ & 0.08 & -0.06 & 0.04 & -0.12 & -0.02 & 0.04 & 0.08 & -0.06 \\
\hline A & $0.41^{*}$ & 0.23 & $0.23^{*}$ & $0.38^{*}$ & $0.33^{*}$ & -0.07 & 0.22 & $0.29^{*}$ & 0.23 \\
\hline
\end{tabular}

Note: $*-$ statistically significant correlation coefficients $(p<0.05)$.

\section{Building of multidimensional statistical models for predicting the content of organic carbon $\left(C_{\text {org }}\right)$}

Since the content of organic carbon in the Domanik type deposits is characterized by an exponential distribution, the values of $\mathrm{C}_{\text {org }}$ were prologized $\left(\ln \left(\mathrm{C}_{\text {org }}\right)\right)$.

As a result of stepwise regression analysis [40] prediction models of $\ln \left(\mathrm{C}_{\text {org }}\right)$ for the sediments, as well as for the Domanik horizon, respectively were obtained:

$$
\begin{gathered}
\ln \left(\mathrm{C}_{\text {org }}\right)=0,62360-1,26968 \mathrm{TNN} 1+ \\
+0,64468 \mathrm{TNN} 2-0,36478 \mathrm{GGD}- \\
-0,17218 \mathrm{GR}, R^{2}=0,497 \\
F(4,468)=115,66, p<10^{-5}
\end{gathered}
$$




$$
\begin{gathered}
\ln \left(\mathrm{C}_{\mathrm{org}}\right)=0,94253-1,20507 \mathrm{TNN} 1+ \\
+0,45769 \mathrm{TNN} 2-0,22918 \mathrm{GGD}- \\
-0,12646 \mathrm{GR}, R^{2}=0,497 \\
F(4,202)=49,945, p<10^{-5} .
\end{gathered}
$$

From the above multidimensional models, it can be seen that the TNN1 indications characterizing the hydrogen content of rocks have the greatest effect on the $\ln \left(\mathrm{C}_{\text {org }}\right)$ forecast [16]. The reduced TNN2 values indicate the presence of voids in the rock and the possibility of accumulation of organic matter in them. A positive angular coefficient in the TNN2 readings arises due to the fact that this method makes a correction to the model (measures the properties of the bottomhole formation zone). The feedback between $\mathrm{C}_{\text {org }}$ and GGD is explained by the fact that with increasing density of the rock, the volume of voids and, consequently, the amount of organic matter is reduced. The presence of a negative angular coefficient for GR is related to the fact that deposits of the Domanik type are represented mainly by carbonates of varying degrees clay and bituminous.

By well logging curves, using the models obtained, $\ln \left(\mathrm{C}_{\text {org }}\right)$ values were calculated, which resulted in true $\mathrm{C}_{\text {org }}$ values, and then Corg values were averaged over the well section for mapping.

\section{Analysis of changes in the content of organic carbon in the sediments of the Domanik time in the Perm Region}

As a result of using multidimensional models, maps of organic carbon content for the Domanic type deposits in general (Fig. 2, a) and the Domanik horizon (Fig. 2, b) were constructed. As an example, we describe the map of organic carbon content in sediments of the Domanik time.

Analysis of Fig. 2, $b$ showed that the Semiluksky deposits are mostly classified as Domanikites $\left(\mathrm{C}_{\text {org }}>5 \%\right)$. Plots with a high content of organic carbon are noted: in the southeastern and northeastern parts of the
Rakshinskaya saddle in Lysekhinskaya well no. $10\left(\mathrm{C}_{\text {org }}=16.4 \%\right)$ and in Dolganovsk well no. $1\left(\mathrm{C}_{\text {org }}=16.35 \%\right)$, respectively; in the southern part of the Perm arch in Osinskaya well no. $1\left(\mathrm{C}_{\text {org }}=14.63 \%\right)$, confined to the outer sideboard zone of the KKSD, in the northern and southern parts of the Babkin saddle in Turkinsky well no. $53\left(\mathrm{C}_{\mathrm{org}}=15.3 \%\right)$ and Kachinskaya well no. $574\left(\mathrm{C}_{\text {org }}=14.58 \%\right)$, respectively, confined to the inner sideboard zone of the KKSD; in the southern part of the Bym-Kungur monocline in Dorokhovskoy well no. $1\left(\mathrm{C}_{\text {org }}=17.3 \%\right)$, confined to the outer side-zone of the KKSD. On the territory of the Bashkir arch, there are high values in the northern and eastern parts of Chaykinskaya well no. $93\left(\mathrm{C}_{\text {org }}=15.35 \%\right)$ and in Shurtan well no. $152\left(\mathrm{C}_{\text {org }}=17.93 \%\right)$, respectively, confined to the inner sideboard zone of the KKSD, as well as in the western part of Dubovogorskaya well no. $2\left(\mathrm{C}_{\text {org }}=17.2 \%\right)$, confined to the inner sideboard zone of the KKSD.

The minimum content of organic carbon is typical: for the northern and the southern parts of the Upper Kama depression in Ocherskaya well no. $1\left(\mathrm{C}_{\mathrm{org}}=1.43 \%\right)$ and Cyril well no. 101 $\left(\mathrm{C}_{\text {org }}=1.46 \%\right)$, respectively; for the central part of the Rakshinsky saddle in Garinsky well no. 62 $\left(\mathrm{C}_{\text {org }}=1.56 \%\right)$.

The map of the average content of organic carbon (see Fig. 2, a) in the Domanik type sediments as a whole (C1t-D3sr) is characterized by less differentiation of values, while local peaks of high concentrations of $\mathrm{C}_{\text {org }}$ were obtained in three wells (in the northern parts of the Babkin saddle and Solikamsk depression).

\section{Conclusions}

1. It has been established that, within Perm Region, the best chemical and bitumen indicators of the Domanik type deposits are characteristic of the Solikamsk Depression territory.

2. In the Domanik type sediments, allochthonous bitumoids prevail over autochthonous ones. 
3. Within the entire thickness of the Domanik deposits, the Domanik horizon is characterized by the best geochemical indicators and according to the classification of K.F. Rodionova belongs to the category of very good source rocks.

4. Multidimensional statistical models for predicting the content of organic carbon $\mathrm{C}_{\text {org }}$ of the Domanik type deposits in general and of the Domanik horizon have been constructed.

5. As a result of the use of multidimensional models, maps of average organic carbon content were constructed across the territory of the Perm Region taking into account the well logging data.

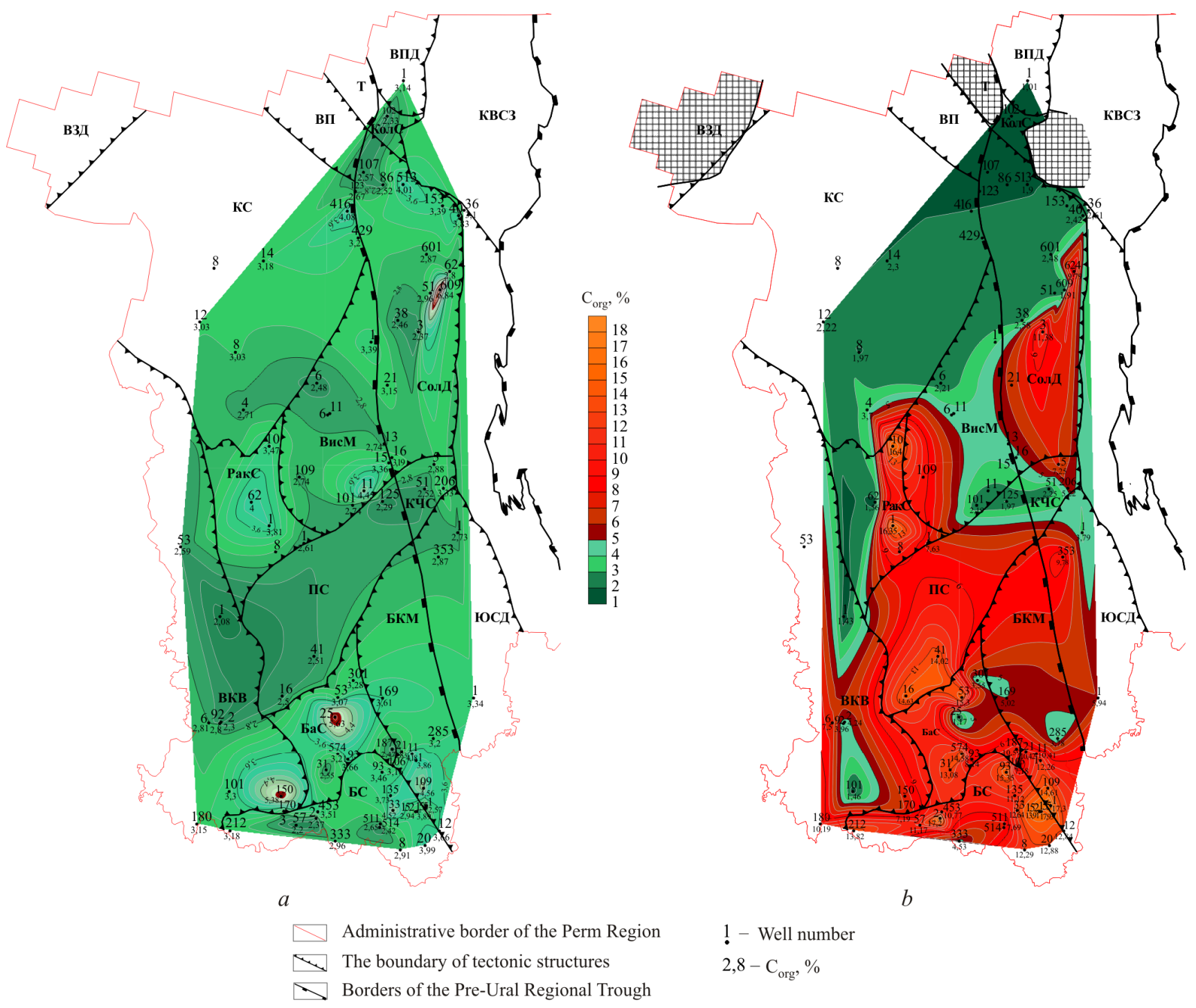

Fig. 2. Map of the average content of organic carbon $\left(\mathrm{C}_{\mathrm{org}}, \%\right)$ in the deposits of Domanik type as a whole $(\mathrm{C} 1 \mathrm{t}-\mathrm{D} 3 \mathrm{sr})(a)$ and Semiluksky (Domanik) time $(\mathrm{D} 3 \mathrm{dm})(b)$ in the Perm Region. Tectonic elements: ВЗД - Vyatka Dislocation Zone; ВКВ - Upper Kama depression; Т - Timan ridge; ЦУП - Central Ural uplift; ВП - Vychegodsky deflection; БС - Bashkir dome; ВисМ - Visim monocline; ВПД - Upper Pechersk depression; ЮСД - Yuryuzano-Sylvenskaya depression; КЧС - Kosvinsko-Chusovskaya saddle; КолС - Kolvinskaya saddle; СолД - Solikamsk Depression; КВС3 - Kozhim-Visherskaya structural zone; ЯЧС3 - Yazva-Chusovskaya structural zone; КС - Kama arch; БаC - Babkin saddle;

БКМ - Bym-Kungur monocline; ПС - Perm arch; РакС - Rakshinskaya saddle 


\section{References}

1. Tisso B., Velte D. Obrazovanie i rasprostranenie nefti [The formation and distribution of oil]. Perevod $\mathrm{s}$ angliiskogo A.I. Koniukhov, G.V. Semernikova, V.V. Chernysheva; ed. N.B. Vassoevich, R.B. Seiful-Muliukov. Moscow, Mir, 1981, 504 p.

2. Vassoevich N.B. Izbrannye trudy. Geokhimiia organicheskogo veshchestva i proiskhozhdenie nefti [Selected works. Geochemistry of organic matter and the origin of oil]. Moscow, Nauka, 1986, 368 p.

3. Galkin V.I., Kochneva O.E. Geologiia i geokhimiia nefti i gaza [Geology and geochemistry of oil and gas]. Perm', Izdatel'stvo Permskogo natsional'nogo issledovatel'skogo politekhnicheskogo universiteta, 2012, $173 \mathrm{p}$.
4. Liadova
N.A.,
Iakovlev
Iu.A., Raspopov A.V. Geologiia i razrabotka neftianykh mestorozhdenii permskogo kraia [Geology and development of oil fields of the Perm region]. Moscow, 2010, 335 p.

\section{Neruchev S.G., Rogozina E.K.} Neftegazoobrazovannie $\mathrm{V}$ otlozheniiakh domanikovogo tipa [Oil and gas formation in Domanik type deposits]. Leningrad, Nedra, 1986, 247 p.

6. Gavrilov V.P., Galushkin Iu.I. Geodinamicheskii analiz neftegazonosnykh basseinov (basseinovoe modelirovanie) [Geodynamic analysis of oil and gas basins (basin modeling)]. Moscow, Nedra, 2010, 227 p.

7. Tissot B.P., Welte D.H. Petroleum formation and occurrence. 2 ed. SpringerVerlag, Berlin, Heidelberg, 1984, 699 p.

8. Hunt J.M. Petroleum geochemistry and geology. 2 ed. Ed. W.H. Freeman, Company. New York, 1996, 743 p.

9. Peters K.E., Cassa M.R. Applied sourcerock geochemistry. Eds. L.B. Magoon, W.G. Dow. The Petroleum System-From Source to Trap. American Association of Petroleum Geologists Memoir, 1994, vol.60, pp.93-120.

10. Stupakova A.V., Fadeeva N.P., Kalmykov G.A., Bogomolov A.Kh.,
Kiriukhina T.A., Korobova N.I., Shardanova T.A., Suslova A.A., Sautkin R.S., Poludetkina E.N., Kozlova E.V., Mitronov D.V., Korkots F.V. Poiskovye kriterii nefti i gaza $\mathrm{v}$ domanikovykh otlozheniiakh volgo-uralskogo basseina [Criteria for oil and gas search in domanic deposits of the Volga-Ural basin]. Georesursy, 2015, no.2 (61), pp.77-86. DOI: 10.18599/grs.61.2.7

11. Nosov M.A., Galkin V.I., Krivoshchekov S.N., Melkishev O.A. Otlozheniia domanikovogo tipa vozmozhnyi istochnik netraditsionnykh uglevodorodov dlia Permskogo kraia: obzor, perspektivy, rekomendatsii [Domanik type rocks - a possible source of non-conventional hydrocarbons for the Perm region: an overview, perspectives, recommendations]. Oil industry, 2012, no.10, pp.90-91.

12. Ilin N.Iu. et al. Provedenie kompleksnykh geokhimicheskikh issledovanii domanikitov verkhnego devona $\mathrm{s}$ tseliu otsenki perspektiv dobychi slantsevogo gaza i slantsevoi nefti na territorii Respubliki Tatarstan: o otchet o NIR [Conducting of complex geochemical studies of the Upper Devonian Domanikites to assess the prospects for the extraction of shale gas and shale oil in the territory of the Republic of Tatarstan: a scientific report]. Kazan, 2013, 71 p.

13. Belokon T.V., Kutukov A.V. Usloviia nefteobrazovaniia $\mathrm{v}$ verkhnedevonskikh nizhnesredne-kamennougolnykh karbonatnykh kompleksakh Volgo-Viatskogo raiona [Conditions of oil formation in the Upper Devonian lower-middle-carbonaceous carbonate complexes of the Volga-Vyatka region]. Geologiia nefti i gaza, 1984, no.2, pp.52-56.

14. Isaev V.P. Geokhimiia nefti i gaza: kurs lektsii [Geochemistry of oil and gas: a course of lectures]. Irkutsk, Izdatelstvo irkutskogo gosudarstvennogo universiteta, 2010, 197 p.

15. Vasilev V.V. Metody otsenki kachestva neftegazomaterinskikh porod [Methods for assessing the quality of oil and gas source rocks]. Ukhta, Ukhtinskii gosudarstvennyi tekhnicheskii universitet, 2012, 56 p. 
16. Baranova T.E., Ilina A.A., Frolovskaia V.N. Rukovodstvo po metodike liuminestsentnobituminologicheskikh issledovanii [Guide to the methodology of luminescent-bitumen research]. Leningrad, Nedra, 1966, 112 p.

17. Bazhenova O.K., Burlin Iu.K., Sokolov B.A., Khain V.E. Geologiia i geokhimiia nefti $i$ gaza [Geology and geochemistry of oil and gas]. Ed. B.A. Sokolov. Moscow, Izdatelstvo Moskovskogo gosudarstvennogo universiteta, 2000, $384 \mathrm{p}$.

18. Kozlova I.A., Galkin V.I., Vantseva I.V. $\mathrm{K}$ otsenke perspektiv neftegazonosnosti solikamskoy depressii s pomoshchyu geologo-geokhimicheskikh kharakteristik neftegazomaterinskikh porod [Evaluation of petroleum potential of solikamsk depression based on geological and geochemical characteristics of oil and gas source rocks]. Oilfield engineering, 2010, no.7, pp.20-23.

19. Neruchev S.G. Neftematerinskie svity i migratsiia nefti [Formation source rocks and oil migration]. Lenigrad, Nedra, 1969, 201 p.

20. Charsky A., Herron S. Accurate, direct total organic carbon (TOC) log from a new advanced geochemical spectroscopy tool: comparison with conventional approaches for TOC estimation. Search and Discovery, 2013, article no.41162, $17 \mathrm{p}$.

21. Devis Dzh.S. Statisticheskii analiz dannykh $\mathrm{v}$ geologii [Statistical analysis of data in geology]. Book 1, 2. Moscow, Nedra, 1990, 426 p.

22. Orlov A.I. Prikladnaia statistika [Applied Statistics]. Moscow, Ekzamen, 2006, 672 p.

23. Kobzar A.I. Prikladnaia matematicheskaia statistika: dlia inzhenerov i nauchnykh rabotnikov [Applied Mathematical Statistics: for engineers and scientists]. Moscow, Fizmatlit, 2012, 816 p.

24. Rodionov D.A., Kogan R.I., Golubeva V.A. et al. Spravochnik po matematicheskim metodam v geologii [Handbook of mathematical methods in geology]. Moscow, Nedra, 1987, 335 p.

25. Davis J.C. Statistics and data analysis in geology. 3rd ed. John Wiley \& Sons, 2002, 656 p.
26. Isaaks E.H., Srivastava R.M. An introduction to applied geostatistics. Oxford University Press, 1989, 561 p.

27. Bakirov A.A., Tabasaranskii Z.A., Bordovskaia M.V., Maltseva A.K. Geologiia i geokhimiia nefti i gaza [Geology and geochemistry of oil and gas]. Ed. A.A. Bakirov, Z.A. Tabasaranskii. Moscow, Nedra, 1982, 288 p.

28. Rodionova K.F., Maksimov S.P. Geokhimiia organicheskogo veshchestva i neftematerinskie porody fanerozoia [Organic matter geochemistry and source rocks of the Phanerozoic]. Moscow, Nedra, 1981, 367 p.

29. Dewan J.T. Essentials of modern openhole log interpretation. PennWell Books, 1983, 361 p.

30. Kang Chen, Jinchuan Zhang, Xuan Tang. Shale oil and gas well logging evaluation in Liaohe depression. International Forum on Energy, Environment Science and Materials, 2015 International Forum on Energy, Environment Science and Materials. DOI: 10.2991/ifeesm-15.2015.37

31. Mahmood M.F., Ahmad Z., Ehsan M. Total organic carbon content and total porosity estimation in unconventional resource play using integrated approach through seismic inversion and well logs analysis within the Talhar Shale, Pakistan. Journal of Natural Gas Science and Engineering, 2018, 52, pp.13-24. DOI: 10.1016/j.jngse.2018.01.016

32. Mehdi Khoshnoodkia, Hassan Mohseni, Omeid Rahmani, Akbar Mohammadi. TOC determination of Gadvan Formation in South Pars Gas field, using artificial intelligent systems and geochemical data. Journal of Petroleum Science and Engineering, 2011, vol.78, iss.1, pp.119-130. DOI: 10.1016/j.petrol.2011.05.010

33. Popov E.Y., Popov Y.A., Gabova A.V., Chekhonin E.M., Romushkevich R.A., Spassenykh M.Y., Stenin V.P., Kozlova E.Y., Deliya S.V., Shayakhmetov T.R., Drandusov K.A. Results of combined investigations of domanic formation with continuous thermal core profiling. Geomodel 2017 -19th Science and Applied Research Conference on Oil and Gas 
Geological Exploration and Development, 2017, September. DOI: 10.3997/2214-4609.201702291

34. Quirein J., Praznik G., Galford J., Chen S., Murphy E., Witkowsky J. A workflow to evaluate mineralogy, porosity, TOC, and hydrocarbon volume in the Eagle Ford Shale. SPE Unconventional Resources Conference and Exhibition-Asia Pacific, 11-13 November, Brisbane, 2013, pp. 189-205. DOI: 10.2118/167012-MS

35. Sun S.Z., Sun Y., Sun C., Liu Z., Dong N. Methods of calculating total organic Carbon from well logs and its application on rock's properties analysis. Search and Discovery, 2014, Article no.41372, available at: http://www.searchanddiscovery.com/documents/2014/41372sun/ndx sun.pdf (accessed 11 June 2018).

36. Atarita T.C., Karlina D.A., Nuratmaja S., Puspitasari A., Santosa B.J. Predicting Distribution of total organic carbon (TOC) and S2 with $\Delta \log$ resistivity and acoustic impedance inversion on Talang Akar Formation, Cipunegara Sub Basin, West Java. Procedia Engineering, 2017, vol.170, pp. 390-397. DOI: 10.1016/j.proeng.2017.03.063
37. Wang P., Peng S.-P., Du W.-F., Feng F.-S. Prediction model of total organic carbon content on hydrocarbon source rocks in coal measures based on geophysical well logging. Journal of the China Coal Society, 2017, 42 (5), pp.1266-1276. DOI: 10.13225/j.cnki.jccs.2016.1237

38. Yosar Fatahillah, Widya Utama, Kukuh Suprayogi, Anik Hilyah, Iqbal Maulana. Source rock formation evaluation using TOC \& Ro log model based on well-log data procesing: study case of Ngimbang formation, North East Java basin. MATEC Web Conf., 2017, vol.101. DOI: $10.1051 /$ matecconf $/ 201710104016$

39. Dreiper N., Smit G. Prikladnoi regressionnyi analiz. Mnozhestvennaia regressiia [Applied regression analysis. Multiple regression]. 3 ed. Moscow, Dialektika, 2007, 912 p.

40. Koskov V.N. Geofizicheskie issledovaniia skvazhin [Well logging]. Perm', Izdatel'stvo Permskogo natsional'nogo issledovatel'skogo politekhnicheskogo universiteta, 2004, 122 p.

\section{Библиографический список}

1. Тиссо Б., Вельте Д. Образование и распространение нефти: пер. с англ. / пер. А.И. Конюхов, Г.В. Семерникова, В.В. Чернышева; под ред. Н.Б. Вассоевича, Р.Б. Сейфуль-Мулюкова. - М.: Мир, 1981. - 504 c.

2. Вассоевич Н.Б. Избранные труды. Геохимия органического вещества и происхождение нефти. - М.: Наука, 1986. - 368 с.

3. Галкин В.И., Кочнева О.Е. Геология и геохимия нефти и газа: учеб.-метод. пособие. - Пермь: Изд-во Перм. нац. исслед. политехн. ун-та, 2012. - 173 с.

4. Лядова Н.А., Яковлев Ю.А, Распопов А.В. Геология и разработка нефтяных месторождений Пермского края / ОАО «ВНИИОЭНГ». - М., 2010. - 335 с.

5. Неручев С.Г., Рогозина Е.К. Нефтегазообразованние в отложениях доманикового типа. - Л.: Недра, 1986. - 247 с.
6. Гаврилов В.П., Галушкин Ю.И. Геодинамический анализ нефтегазоносных бассейнов (бассейновое моделирование): учеб. для вузов. - М.: Недра, 2010. - 227 с.

7. Tissot B.P., Welte D.H. Petroleum formation and occurrence. - 2 ed. - SpringerVerlag, Berlin, Heidelberg, 1984. - 699 p.

8. Hunt J.M. Petroleum geochemistry and geology. -2 ed. - New York, 1996. - 743 p.

9. Peters K.E., Cassa M.R. Applied sourcerock geochemistry // The Petroleum SystemFrom Source to Trap / Eds. L.B. Magoon, W.G. Dow; American Association of Petroleum Geologists Memoir. - 1994. - Vol. 60. - P. 93-120.

10. Поисковые критерии нефти и газа в доманиковых отложениях Волго-Уральского бассейна / А.В. Ступакова, Н.П. Фадеева, Г.А. Калмыков, А.Х. Богомолов, Т.А. Кирюхина, Н.И. Коробова, Т.А. Шарданова, А.А. Суслова, Р.С. Сауткин, Е.Н. Полудеткина, Е.В. Козлова, 
Д.В. Митронов, Ф.В. Коркоц // Георесурсы. 2015. - № 2 (61). - С. 77-86. DOI: $10.18599 /$ grs.61.2.7

11. Отложения доманикового типа возможный источник нетрадиционных углеводородов для Пермского края: обзор, перспективы, рекомендации / М.А. Носов, В.И. Галкин, С.Н. Кривощёков, О.А. Мелкишев // Нефтяное хозяйство. 2012. - № 10. - С. 90-91.

12. Проведение комплексных геохимических исследований доманикитов верхнего девона с целью оценки перспектив добычи сланцевого газа и сланцевой нефти на территории Республики Татарстан: отчет о НИР / Казан. федер. ун-т, рук. Н.Ю. Ильин, исполн.: Н.Ю. Ильин [и др.]. - Казань, 2013. - $71 \mathrm{c}$.

13. Белоконь Т.В., Кутуков А.В. Условия нефтеобразования в верхнедевонских нижнесреднекаменноугольных карбонатных комплексах Волго-Вятского района // Геология нефти и газа. - 1984. - № 2. C. 52-56.

14. Исаев В.П. Геохимия нефти и газа: курс лекций. - Иркутск: Изд-во Иркут. гос. ун-та, 2010. - 197 с.

15. Васильев В.В. Методы оценки качества нефтегазоматеринских пород: учеб. пособие. - Ухта: Ухтин. гос. техн. ун-т, 2012. - 56 c.

16. Баранова Т.Э., Ильина А.А., Фроловская В.Н. Руководство по методике люминесцентно-битуминологических исследований. - Ленинград: Недра, 1966. - 112 с.

17. Геология и геохимия нефти и газа: учеб. / О.К. Баженова, Ю.К. Бурлин, Б.А. Соколов, В.Е. Хаин; под ред. Б.А. Соколова. М.: Изд-во Моск. гос. ун-та, 2000. - 384 с.

18. Козлова И.А., Галкин В.И., Ванцева И.В. К оценке перспектив нефтегазоносности Соликамской депрессии с помощью геолого-геохимических характеристик нефтегазоматеринских пород // Нефтепромысловое дело. - 2010. - № 7. - С. 20-23.
19. Неручев С.Г. Нефтематеринские свиты и миграция нефти. - Л.: Недра, 1969. - 201 c.

20. Charsky A., Herron S. Accurate, direct total organic carbon (TOC) log from a new advanced geochemical spectroscopy tool: comparison with conventional approaches for TOC estimation // Search and Discovery. 2013. - July 31. - 17 p.

21. Девис Дж.С. Статистический анализ данных в геологии. - М.: Недра, 1990. Кн. 1 и $2 .-426$ с.

22. Орлов А.И. Прикладная статистика: учеб. - М.: Экзамен, 2006. - 672 с.

23. Кобзарь А.И. Прикладная математическая статистика: для инженеров и научных работников. - М.: Физматлит, 2012. $-816 \mathrm{c}$.

24. Справочник по математическим методам в геологии / Д.А. Родионов, Р.И. Коган, В.А. Голубева [и др.]. М.: Недра, 1987. - 335 с.

25. Davis J.C. Statistics and data analysis in geology. - 3rd ed. - John Wiley \& Sons, 2002. $-656 \mathrm{p}$.

26. Isaaks E.H., Srivastava R.M. An introduction to applied geostatistics. - Oxford: University Press, 1989. - 561 p.

27. Геология и геохимия нефти и газа / А.А. Бакиров, 3.А. Табасаранский, М.В. Бордовская, А.К. Мальцева; под ред. А.А. Бакирова, 3.А. Табасаранского. М.: Недра, 1982. -288 с.

28. Родионова К.Ф., Максимов С.П. Геохимия органического вещества и нефтематеринские породы фанерозоя. - М.: Недра, 1981. - 367 c.

29. Dewan J.T. Essentials of modern openhole $\log$ interpretation. - PennWell Books, 1983. - $361 \mathrm{p}$.

30. Kang Chen, Jinchuan Zhang, Xuan Tang. Shale oil and gas well logging evaluation in liaohe depression // International Forum on Energy, Environment Science and Materials, 2015 International Forum on Energy, 
Environment Science and Materials. DOI: 10.2991/ifeesm-15.2015.37

31. Mahmood M.F., Ahmad Z., Ehsan M. Total organic carbon content and total porosity estimation in unconventional resource play using integrated approach through seismic inversion and well logs analysis within the Talhar Shale, Pakistan // Journal of Natural Gas Science and Engineering. - 2018. - 52. - P. 13-24. DOI: 10.1016/j.jngse.2018.01.016

32. TOC determination of Gadvan Formation in South Pars Gas field, using artificial intelligent systems and geochemical data / Mehdi Khoshnoodkia, Hassan Mohseni, Omeid Rahmani, Akbar Mohammadi // Journal of Petroleum Science and Engineering. 2011. - Vol. 78, iss. 1. - P. 119-130. DOI: 10.1016/j.petrol.2011.05.010

33. Results of combined investigations of domanic formation with continuous thermal core profiling / E.Y. Popov, Y.A. Popov, A.V. Gabova, E.M. Chekhonin, R.A. Romushkevich, M.Y. Spassenykh, V.P. Stenin, E.Y. Kozlova, S.V. Deliya, T.R. Shayakhmetov, K.A. Drandusov // Geomodel 2017 - 19th Science and Applied Research Conference on Oil and Gas Geological Exploration and Development. - 2017. September. DOI: 10.3997/2214-4609.201702291.

34. A workflow to evaluate mineralogy, porosity, TOC, and hydrocarbon volume in the Eagle Ford Shale / J. Quirein, G. Praznik, J. Galford, S. Chen, E. Murphy, J. Witkowsky // SPE Unconventional Resources Conference and Exhibition-Asia Pacific, 11-13 November. - Brisbane, 2013. - P. 189-205. DOI: 10.2118/167012-MS

35. Methods of calculating total organic carbon from well logs and its application on rock's properties analysis [Электронный pecypc] / S.Z. Sun, Y. Sun, C. Sun, Z. Liu, N. Dong // Search and Discovery. - 2014. - Article № 41372 - URL: http://www.searchanddiscovery.com/documents/2014/41372sun/ndx_sun. pdf (дата обращения: 11.06.2018).

36. Predicting distribution of total organic carbon (TOC) and $\mathrm{S} 2$ with $\Delta$ Log resistivity and acoustic impedance inversion on Talang Akar Formation, Cipunegara Sub Basin, West Java / T.C. Atarita, D.A. Karlina, S. Nuratmaja, A. Puspitasari, B.J. Santosa // Procedia Engineering. - 2017. - Vol. 170. P. 390-397. DOI: 10.1016/j.proeng.2017.03.063

37. Prediction model of total organic carbon content on hydrocarbon source rocks in coal measures based on geophysical well logging Meitan Xuebao / P. Wang, S.-P. Peng, W.-F. Du, F.-S. Feng // Journal of the China Coal Society. - 2017. - 42 (5). - P. 1266-1276. DOI: $10.13225 /$ j.cnki.jccs.2016.1237

38. Source rock formation evaluation using TOC \& Ro log model based on well-log data procesing: study case of Ngimbang formation, North East Java basin / Yosar Fatahillah, Widya Utama, Kukuh Suprayogi, Anik Hilyah, Iqbal Maulana // MATEC Web Conf. - 2017. - Vol. 101. DOI: $10.1051 /$ matecconf $/ 201710104016$

39. Дрейпер Н., Смит Г. Прикладной регрессионный анализ. Множественная регресссия. - 3-е изд. - М.: Диалектика, 2007. - С. 912.

40. Косков В.Н. Геофизические исследования скважин: учеб. пособие. Пермь: Изд-во Перм. гос. техн. ун-та, 2004. -122 c.

Please cite this article in English as:

Raznicyn A.V., MelkishevO.A. The study of luminescent-bitumen characteristics of organicsubstances of Domanik type deposits in the Perm region. Perm Journal of Petroleum and Mining Engineering, 2019, vol.19, no.1, pp.15-25. DOI: $10.15593 / 2224-9923 / 2019.1 .2$

Просьба ссылаться на эту статью в русскоязычных источниках следующим образом:

Разницын А.В., Мелкишев О.А. Изучение люминесцентно-битуминологических характеристик органического вещества отложений доманикового типа на территории Пермского края // Вестник Пермского национального исследовательского политехнического университета. Геология. Нефтегазовое и горноедело. - 2019. - Т.19, №1. - С.15-25. DOI: $10.15593 / 2224-9923 / 2019.1 .2$ 